\title{
Unhealthy Glasgow: a Case for Ecological Public Health?
}

Phil Hanlon MD, MPH

Former Professor of Public Health,

Institute of Health and Wellbeing

College of Medical, Veterinary and Life Sciences

University of Glasgow

1 Lilybank Gardens

Glasgow G12 8RZ

Correspondence to: Phil Hanlon e: phil.hanlon1@btinternet.com hm tel: 01418892835

\section{Contents}

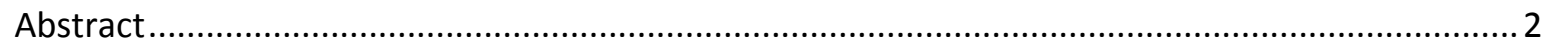

Introduction: unravelling the complexity of Glasgow's public health ............................................ 2

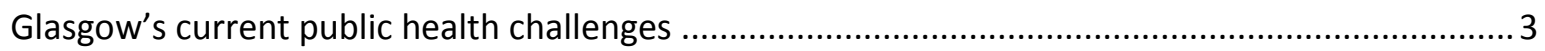

Learning from history: 4 waves of public health challenges and responses .................................. 4

Can ecological public health help address this complex picture? ................................................. 6

Accept that change - often of a profound kind - is inevitable ................................................... 6

Share evidence on multi-dimensional ecological change .......................................................... 6

Make the health-economic dynamic more central to the public health project............................. 7

Take the long view of public health evidence and progress over the last 200 years ..................... 8

Give declining cities more attention in the pursuit of sustainable futures .................................. 9

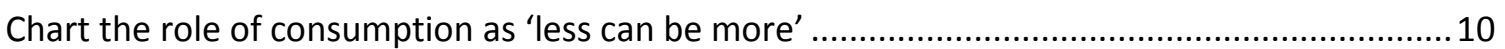

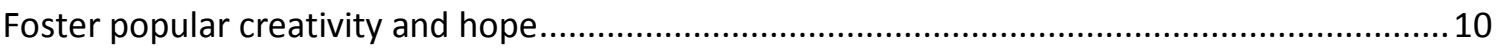

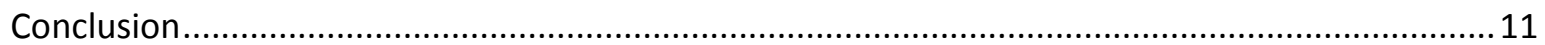

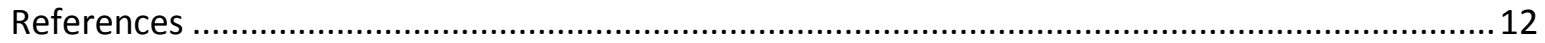




\section{Abstract}

Ecological public health has been proposed as an approach appropriate for addressing the multiple transitions that currently affect human health and sustainability. The paper draws on the author's experience in public health in Glasgow to analyse the health challenges faced by this post-industrial Scottish city. Like other such cities, it not only faces multiple health challenges but also demonstrates a currently unexplained excess mortality that has been dubbed the 'Glasgow Effect'. To explore this troubled mixture, the paper outlines four historical waves of public health challenge and response in Glasgow over the last century, and proposes that a fifth is emerging. The challenge now is how to negotiate environmental sustainability with social, political and economic sustainability to enhance health for all. The paper suggests that gains made by past approaches still need to be protected and can be included within ecological public health, but they lack the wider vision, coherence and capacity required if cities are to address the scale and range of contemporary conditions. A number of lessons are offered for the ecological public health perspective.

\section{Keywords}

Ecological public health; Glasgow Effect; Future of public health; social sustainability;

\section{Introduction: unravelling the complexity of Glasgow's public health}

In recent publications Rayner and Lang have argued that 'ecological public health' should become the prominent approach to improving health in the $21^{\text {st }}$ Century. ${ }^{12}$ This paper considers whether that perspective is relevant to the circumstances of the UK's most unhealthy city - Glasgow. Life expectancy in Glasgow is the lowest of any area in the UK, 72.6 years for males and 78.5 for women in 2010-12, while life expectancy for the highest, East Dorset (in Southern England), was 10.3 more years for males and 8.1 more years for women. ${ }^{3} 75 \%$ of Glasgow-born baby boys and $85 \%$ of baby girls are likely to reach their 65 th birthdays, if 2010-12 mortality rates persist throughout their lifetime. This city is a wellstudied urban setting, with research seeking to explain why its people maintain such poor patterns of health while other cities, in some cases more afflicted by economic decay and social dislocation, have improved. It raises questions about whether Glasgow has specific problems which make it unique or whether its patterns of health are better explained by a complex interrelation of factors, together known as the Glasgow Effect, a more cultural explanation. This paper reflects on that literature and asks whether conventional public health models and methods applied in four historical 'waves' in Glasgow, and seen as effective in the past, still have applicability in the $21^{\text {st }}$ century. These conventional public health approaches appear to be now insufficient. The paper considers whether ecological public health, with its focus on the interplay of material, biological, social and cognitive shaping factors, might offer an analytic and change model better adapted to Glasgow's current needs and circumstances, and contribute to addressing the Glasgow Effect. If depression and despair, lodged in culture, help explain stubborn patterns of poor health and wellbeing, cultural regeneration should therefore provide an important element of health improvement. But if material inequalities persist, might these cultural gains be offset? The 
paper considers whether and how public health in a post-industrial city such as Glasgow can be improved and what its role in a more sustainable society might be. The paper makes a case for more coherent thinking about the future with public health at its heart.

\section{Glasgow's current public health challenges}

With a population of nearly 600,000 people, Glasgow is Scotland's largest city. Located on the banks of the River Clyde, it is the centre of a larger conurbation that has experienced significant industrial decline. ${ }^{4}$ One well documented consequence is that the populations of Glasgow and West Central Scotland (WSC) suffer from a wide range of adverse health and social outcomes. ${ }^{5}$ What is true of Glasgow and its hinterland is also true of other similar regions of the UK and Europe. In a recent study, ten of these regions were selected for analysis (the Ruhr area and Saxony in Germany; Katowice in Poland; Northern Moravia in the Czech Republic; Nord-Pas-de-Calais in France; Wallonia in Belgium; Limburg in the Netherlands; Northern Ireland; Swansea and the coalfields of south Wales; and Merseyside in England). ${ }^{67}$ All these post-industrial regions have poor health and social outcomes compared to their respective national averages. Males from West Central Scotland currently have lower life expectancy than those from each of these other regions except for Katowice in Poland and Northern Moravia in the Czech Republic. The difference is that the rates of improvement in life expectancy in these two regions, compared to WCS, suggest that these regions will overtake WCS in less than 10 years. WCS females also have lower life expectancy than the other selected regions and improvement rates are also faster in the comparator regions. ${ }^{7}$ Importantly, the current economic status of WCS is better than many of these other regions. This suggests that non-economic cultural and socio-economic factors may be involved as health determinants.

Further evidence comes from an elegant comparison of three cities: Glasgow, Liverpool and Manchester. ${ }^{8}$ Liverpool and Manchester stand out because they share with Glasgow high levels of poverty and low life expectancy. Indeed, when the deprivation profiles of the three cities are analysed, there is almost no difference. This means that any difference observed in health outcomes cannot be explained by deprivation because all three manifest the same levels of deprivation. In stark difference, working age adults in Glasgow have 30\% higher mortality than in the two English cities while excess mortality for Glasgow, relative to Liverpool and Manchester, can be seen across the whole population, with all-age mortality around $18 \%$ higher in the most deprived decile and $15 \%$ higher in the least deprived decile. ${ }^{8}$

What can have caused these additional deaths? For both cancers and diseases of the circulatory system, Glasgow has $12 \%$ more deaths. Deaths among Glaswegians are $27 \%$ higher in relation to lung cancer, while smoking rates are almost identical. Glasgow's rates are $32 \%$ higher for external causes and almost $70 \%$ higher for suicide. Glasgow has death rates that are 2.3 times higher for alcohol-related causes, and almost 2.5 times higher for drug-related poisonings. The numbers are significant. Between 2003 and 2007 there were more than 4,500 excess deaths in Glasgow, of which almost half $(2,090)$ occurred under the age of 65 . Analysis by age, sex and cause shows that, for deaths under 65 , almost half of the excess was due to deaths from a combination of alcohol related causes (32\%) and drugs related poisonings $(17 \%){ }^{8}$ 
Perhaps this picture is an historical one of a city with persistent excess deaths but there is evidence to suggest that this excess - the 'Glasgow Effect' - is a relatively recent phenomenon. ${ }^{8}$ This has been confirmed by another multi-city European study. ${ }^{9}$ Analyses of historical data suggest it is unlikely that the deprivation profile of Glasgow has changed significantly relative to Liverpool and Manchester in recent decades; moreover, the mortality gap appears to have widened since the early 1970s. These results emphasise that, while deprivation is a fundamental determinant of health and an important driver of mortality, it constitutes only one part of a more complex picture. Additional explanatory factors are required. Importantly, these mortality data must be supplemented by an awareness of morbidity: Glasgow's population suffers from high levels of morbidity from non-communicable diseases, mental health problems, obesity and a wide range of social problems. $^{4}$

\section{Learning from history: 4 waves of public health challenges and responses}

Like all urban settlements, Glasgow is marked by its past. In Glasgow, the industrial revolution brought overcrowding, poor sanitation, poor nutrition and water supplies and an appalling built environment. ${ }^{10-13}$ These conditions created the ideal milieu for almost all forms of infection. At the same time, recorded levels of alcohol consumption, crime and 'illegitimacy' (to quote just three indices) were so high that they suggest real strains on psychological wellbeing and social ties, which is why one strand of social comment since Victorian times introduced and sometimes over-stated the moral sphere in explanations. ${ }^{14}$

Since the city rapidly expanded with industrialisation and trade, four waves of public health improvement in Glasgow can also be identified. ${ }^{15}$ The first wave (approximately 1830 1890 ) is associated with great public works and other developments arising from responses to the social disruptions which followed the industrial revolution. A health infrastructure began to be injected: water and food market controls, housing, a medical system, etc. Civic order and prosperity slowly improved and, in time, life expectancy began to rise. ${ }^{4}$ At that stage, Glasgow was an important hub of the most developed industrial economy in the world; it proudly claimed the status of being the 'Second City of the Empire' (as did Liverpool, Calcutta and Birmingham at times). Certainly, Glasgow's entrepreneurs took advantage of natural resources (coals and iron ore) and the city's strategic position as a port on the edge of the Atlantic rapidly to expand and consolidate its mix of trade and manufacturing. ${ }^{16}$

A second wave (approximately 1890-1950) saw improved living conditions and nutrition, not just in Glasgow but across the UK. ${ }^{17,18}$ Scientific rationalism provided breakthroughs in many fields - manufacturing, medicine, engineering, transport, and communications. The development of vaccines became a symbol of medical progress in this era. ${ }^{15,19}$ Over the same period, however, Glasgow's comparative economic advantage began to wane, with the loss of competitiveness also creating adverse effects early in the $20^{\text {th }}$ century. ${ }^{20-22}$ One consequence was that public health interventions operated with scarcer resources and became less guided by an integrated approach to public health. ${ }^{21}$ 
The third wave (approximately 1940-1980) saw the installation of the UK-wide welfare state: the National Health Service, social security, social housing and universal education. ${ }^{23}$, ${ }^{24}$ These policy interventions were the result of pressure for social reform before, during and after World War $2 ;^{25}$ even so it was not until the economic upturn in the late 1950 s and early 1960s that large scale regeneration projects began to get underway with any serious intent in Glasgow. ${ }^{21}$ These too often lacked an integrated perspective and were widely recognised to have failed their populations with respect to the wider social infrastructure that would have been necessary to sustain flourishing communities. Lack of funds produced a poor quality housing stock that was difficult to heat, prone to dampness and in need of frequent repair. ${ }^{2627}$ The economic downturn and loss of manufacturing jobs in the 1980s (precipitated by rising oil prices) increased inequalities and led to calls for a more imaginative public health approach. ${ }^{28}$

A more thoughtful approach did arrive in the form of the Healthy Cities movement. In 1986 the WHO's Ottawa Charter called for five key actions: the building of 'healthy public policy'; the creation of supportive environments; the strengthening of community actions; the development of personal skills; and the reorientation of health services towards primary care. $^{29}$ It also spawned the 'Healthy Cities' movement, ${ }^{30-32}$ and Glasgow became an early member of the UK and European new network. Although the 'Health for All' philosophy and the principles enshrined in the Ottawa Charter remain relevant and important, the experience of the period also tells us they are not enough; the aspirations remain sound but the institutions and policy mechanisms might be lacking, and the urgency of the case for reorienting human health around ecosystems health has increased. ${ }^{33,34}$ In Glasgow, for all the impact of Healthy Cities, elements within the City resisted these ideas on the ground that they lacked sufficient evidence or were politically impractical. ${ }^{35}$ How could a City suffering de-industrialisation pay for transformed environment, to cite just one feature? Indeed, what may be identified as a wave (in the period approximately 1960-2000) may be typified as a stress on medical and health care intervention aiming to prolong life and control risky behaviours such as actions to tackle diet, exercise, tobacco, alcohol and illegal drugs. ${ }^{36}$ In retrospect, neither medical nor behavioural interventions provided the solutions to newly emergent social pathologies. The healthy cities philosophy, in contrast, provided a different narrative for Glasgow - that regeneration needed to be holistic with municipal bodies acting on housing, environmental, economic, social and cultural regeneration all working together. ${ }^{37}$ In this manner, it was hoped, Glaswegians were to be enabled to become more resilient (in modern language) on the basis of their membership of more cohesive communities with better housing conditions, secure employment, and high quality public services. When such improvements were brought together, it was suggested, a sense of confidence and wellbeing would be fostered and health improved. While this approach attracted widespread support in theory, a spectrum of regeneration activity actually underway in Glasgow paints a more complex, even ambiguous, picture. $^{21}$

Glasgow city has invested unprecedented sums on regeneration, including to its poorest areas, ${ }^{38}$ but it is also a conurbation where ever greater income and wealth flows to the wealthier section of the population. The city's greatest focus for economic growth has been in its retail and service sector in line with many other regions, ${ }^{39}$ and there are important questions now being asked about its economic and social sustainability. This, of all the Ottawa Charter's appeal, remains elusive. The political economy has remained stubbornly 
and largely neo-liberal at the global and UK level, meaning that Glasgow even as a large city has limited capacity to reshape its conditions, but this can lead to dejection and cynicism, no friends of public health.

\section{Can ecological public health help address this complex picture?}

As one who has worked much of this life in Glasgow, and is conscious of the fragility of the wider eco-system on which 'civilisation' depends, ecological public health thinking offers some principles which are fundamentally useful for the kind of experience that Glasgow and other de-industrialised cities experience. The dominant political policy remains wedded to the view that health can be invested in only after wealth has been generated; ecological public health suggests a different policy rule: investment in sustainability for a steady state economy from which equitable conditions for health can follow. ${ }^{40}$ In practice this implies some policies already known such as massive retrofitting of housing, re-engineering of food and transport systems, and the development of a low carbon economy, but ecological public health brings these investments into a coherent framework. If societies genuinely want to ease inequalities or reverse obesity or enhance the quality of life years, the conditions of existence need to be restructured. This requires medium and long term change with clear shared understanding across the public health movement and its allies. A number of insights for what ecological public health means are now considered, drawing on Glasgow's experience.

\section{Accept that change - often of a profound kind - is inevitable}

Ecological thinking since Darwin is premised on understanding complex interactions and constant flux; that purpose and value remains, ${ }^{41}$ despite some fissuring between the broadly bio-ecological and the social-ecological, as Rayner and Lang have noted. ${ }^{42}$ Environmental pressures - climate change and resource scarcity - now suggest some urgency for all urban settlements to consider how to manage coming major change. ${ }^{43-45}$ This may be as profound as the transformation that established the modern world. ${ }^{46} 47$ Even cities which are judged as modern global city successes - London, New York, Beijing - face considerable tensions. Networks such as C40, a coalition of 'world cities' (although not including Glasgow), are beginning to consider how to face climate change but more attention is needed on how cities in decline can 'ride' these changes with dignity and civility, not least with fairer access to resources and investment to prepare for change. The public health sector could and should be actively engaged in this process to ensure urban settlements move in a more rather than less sustainable, equitable and healthy direction. ${ }^{48}$ The 2016 UN Habitat 3 conference is one opportunity for such debate about the confluence of the built, ecosystem and social environment. ${ }^{49} \mathrm{~A}$ consensus is emerging about the inevitability of change but also some key issues on which public health voice is necessary such as slums and sanitation..$^{50}$ In that sense, Glasgow's experience of attempted regeneration is globally valuable. 
The value of $19^{\text {th }}$ century ecological thinking was its emphasis on how different levels of the biosphere interact: flora and fauna, sub- and above-soil, plants and animals. The socialecological perspective that has so strongly influenced contemporary public health thinking owed more perhaps to Chicago planning or Boston's health interventions that to the bioecologists. ${ }^{51}$ In fact, Glasgow's experience requires both ecological traditions. It can only be understood as a mix of physical (e.g. brick, concrete, material), biological (e.g. flows of nutrients and physiological interactions), economic (e.g. finance, for example), social (e.g. interpersonal and social class) and cultural activity. This is what emerges from the literature across not just public health but economic development on Glasgow. Surely, then, Glasgow's health is unlikely to be reshaped only by working on one dimension. And in a world with volatile or limited economic growth, a consumption-led approach to growth is bound to be fragile, allowing lower income groups in only when finance is flowing. This is hardly 'sustainable' development and a key block on the road as charted by those who see public health as following from wealth generated by economic activity. Even the World Bank and IMF now recognize that unsustainable growth cannot continue indefinitely in an unequal system. ${ }^{52,53}$ How much more in a finite ecological system ${ }^{43}$ Arguably, cities by their very existence and expansion put new pressures on eco-systems. ${ }^{54}$ The degradation from expansion is noted worldwide. ${ }^{55,56}$

In the future, cities, whether expanding or shrinking, must become lighter on the earth yet still protect and support benefit their citizens. What can Glasgow with its small population do alongside Mexico City or Lagos with tens of millions? Demographics are again becoming important for public health analysis. Some of the numbers speak for themselves. The human population has risen from around a billion in 1830 to over 7 billion today, with projections suggesting around 9 billion by $2050 .^{57}$ When combined with other factors such as energy and the expansion of credit, and the stresses humanity poses on the biosphere, maintaining such a level of growth will be ever more a challenge. Some analysts chart a future with energy (oil, gas, uranium, etc.) squeezed in material and financial terms - 'peak' thinking about food, oil, phosphates, rare earths, etc. - while others now point to a new era of plenty due to 'fracking' and solar-based technologies or biofuels. One stresses changed consumption; the other to technical innovation and a circular economy (with massive recycling of resources), ${ }^{58}$ backed by the European Commission in $2014 .^{59}$ Whichever future emerges, the landscape, both physical and metaphorical, will change. ${ }^{60}$ Already, despite energy-consciousness since the early 1970s, global energy use and carbon emissions have risen $1971-2012{ }^{61}$ adding to concerns about both resource availability and the consequences. ${ }^{62,63}$ Small declining cities such as Glasgow will not be in a strong place to 'negotiate' in world energy markets, although a wider political restructuring of Scotland's relationship to the UK is underway since devolution which might give new opportunities. ${ }^{64}$ Should public health proponents therefore argue for lower impact economies, anticipating further stress? Probably yes, but only if designed around civilising change for people on low income.

\section{Make the health-economic dynamic more central to the public health project}

Researchers as diverse as McKeown and Fogel have given credence to the dictum, to put it simply, that health follows wealth, that public health investment must follow not precede 
economic growth. ${ }^{65}$ This has a number of political variants, but what if wealth is declining and inequality rising, as with Glasgow, where domestic debt is a problem and the city suffers a fiscal squeeze on social infrastructure? And what if the model does not fit all circumstances? Glasgow's experience of consumer debt and tightening finance for a sizeable percentage of households from the 1980s led to a rebirth of anti-poverty campaigns and a search for more systemic measures such as the Foodworks Inquiry (a citizen-led process). ${ }^{66}$ The link between the money and credit system and health still deserves attention but could be sharpened by better understanding of wider macroeconomic reality of finance capital and its credit swaps, futures markets, bonds and hedge funds, the web of which nearly imploded in 2007-08. (Ironically, financiers have begun to turn to the language of 'ecology' to explain their interdependencies!) Glasgow's funds, like all metropolitan entities, are inevitably caught up in this world of bonds and international finance where money is created by loaning it into existence. ${ }^{67}$ In the years leading up to the credit crunch there was an exponential growth in credit. ${ }^{68}$ As long as loans (with their interest) can be paid off, the economic system functioned but, if there is a major default as there was in 2007-08, the edifice shakes. Preventing collapse is why governments are now recapitalising banks and buying up bad debts but the whole edifice is precarious and is based on continuing economic growth that may be subject to ecological limits that have already been overshot. ${ }^{69}$ In the period since the rescue of the banks and the financial system, credit has continued to expand raising fears of a new 'bubble'. McKinsey Global Institute estimated that global debt has increased by $\$ 57 \mathrm{tn}$ to almost $\$ 200$ tn in the period 200714 ; with China's debt rising to $289 \%$ of GDP in $2014 .{ }^{70}$ Glasgow would not be offered such credit.

Ecological public health thinking stands away from such economics, being critical of its implicit assumption that economic growth automatically leads to health improvement. Indeed, it draws on the argument that health and environmental costs are usually externalised in growth, not fully taken account of in the cost of goods and consumption. More affirmatively, it proposes steady-state economies as a goal preferable to collapse or uncontrolled decline. The key is to engineer a smooth adaptation of the human footprint to the carrying capacity of the globe. ${ }^{69}$ What is not possible, based upon ample evidence of the extent of ecological damage, is for current patterns of growth to continue unabated. If change is inevitable, we have an opportunity to create transformational change. As Joseph Stiglitz, Nobel Laureate in Economics, has argued, the moral imperative is reasserted, ${ }^{71}$ and economics once more becomes the political or moral economy Adam Smith, the eighteenth century economist who taught in Glasgow, first posited. ${ }^{72,73}$

\section{Take the long view of public health evidence and progress over the last 200 years}

If the fundamental changes forecast by resilience scientists now argue, ${ }^{74}$ the public health movement's 200 year old legacy and respect will come under further strain if health and healthcare continues to be subservient to existing mechanisms of wealth generation. Even though an ideal health status has not been achieved, the four waves of public health improvement generated real benefits for Glasgow. The city today, contrasted with the past, has clean water and effective sanitation, access to preventive medicine and all the services of a modern welfare state. Overall levels of nutrition and general prosperity too have risen, even if the city remains marked by deprivation and new patterns of diet-related ill-health. 
Ecological public health may transcend older intervention models but it also has to incorporate them. We must maintain evidence-based public health but build forwardlooking and imaginative work alongside.

Such thinking is already emerging in Glasgow from within the social and public health policy 'constituency' engaging a mix of professions, activists and civil society, much as such forums emerge across the world. ${ }^{75}$ The AFTERnow project, for instance, frames the question 'what next for the health of society?' within a cultural debate about modernity, science and how to live life. ${ }^{76}$ Concerned initially about mental health, it has suggested that many of the health problems today need to be explored as much culturally as structurally or materially. This reassertion of public health as a social project is in line with ecological public health and historical search for an under ${ }^{77}$ standing not just of why things are as they are but for the clues as to how they might be changed. If Glasgow is to continue the civilising project, it requires interdisciplinary, inter-dimensional and imaginative support. What principles or methodologies might therefore be suggested?

As in the past the focus on the collection and interpretation of evidence remains indispensible. Cities today need data tailored to their requirements, something that could be lost in the policy debate about Big Data even though it recognises how data gathering is heavily skewed to power élites. ${ }^{78}$ The creation of the Glasgow Centre for Population Health as a collaboration of city and academia is and was significant for the investigation of Glasgow's excess mortality. Many hypotheses are being investigated using rigorous but largely conventional methods. Important foci include: migration; differing health behaviours; divergent values and cultures; the influence of cultures of substance misuse; boundlessness and alienation; family structures, gender relations and parenting differences; low social capital; sectarianism; limited social mobility; health service supply or demand; deprivation concentrations, inequalities; patterns of deindustrialisation; political attack, and climatic differences (for example, the link between sunlight and Vitamin D). These studies yield important insights; to date no single overarching explanation has been found. For example, differences in health related behaviours and risks (like smoking, diet and blood pressure) do not, at least from the data currently available, explain the excess. It may be that no single causes for Glasgow's excess mortality may be found; indeed it is likely that the explanation can only be found in patterns of complexity. The Glasgow Effect shows the need for narrative; if public health advocates do not create theirs, others will, most likely tinged with moralism it finds less desirable.

\section{Give declining cities more attention in the pursuit of sustainable futures}

Glasgow needs a vision for a sustainable, equitable and healthy future. That vision does not currently exist. The footprint of cities in middle income countries is following the path created by predecessors from the industrialised world like Glasgow yet this route is wasteful and unsustainable. Thoughtless consumption is an environmental folly, accentuating global divisions of labour and inequalities hidden by long supply chains and perpetuating unfair resource-use. ${ }^{79}$ Already all humanity consumes resources as though there are 1.5 planets but the USA consumes as though there are at least three planets. In 2010 , according to the 
latest Global Footprint Report, there was an average of 1.7 global hectares (gha) available to provide bio-capacity for each human on earth. North America actually used nearly 7 gha, the EU 4.5, Asia and China 1.7, and Africa just under the notional average. That profound health problems follow from this inequality and resource depletion has long been recognised. ${ }^{80,81}$ The deeper thinking required on what to do about it - turning from diagnosis to prognosis is now emerging from within the public health movement, particularly around climate change. The 2014-15 UCL Lancet Commission, for example, moved beyond warnings of dire consequences from business-as-usual to the advantages for health of low impact living. "There are major health benefits from low-carbon living with potential reductions in obesity, heart disease, diabetes and respiratory illness". ${ }^{82,83}$ Similar gains would follow from a reversal of a consumption and energy-use driven obesogenic environment. ${ }^{84}$ Such paths can be drawn by academics and science, but it requires public support. That process has barely begun. Glasgow, and all cities, need to create a new civic conversation to redefine what is meant by progress; the growth of civil society organisations who see this is heartening. ${ }^{85,86}$

\section{Chart the role of consumption as 'less can be more'}

A particularly thorny issue for ecological public health is the issue of consumption. Appeals to consume less or more wisely are easily dismissed a appealing to those already prosperous. The dietary patterns of ill-health expose a large measure of malconsumption. Yet the data point to Western societies collectively weighed by a consumerist clutter of life, encouraged by advertising, the manipulation of taste, the promotion of waste and an appeal to choice ideology. ${ }^{87}$ The challenge of sustainability means, in colloquial terms, learning to live with 'less stuff' (and perhaps 'better stuff'), a principle of simplicity and clarity of life effectively captured by architect Ludwig Mies van der Rohe's dictum 'Less is More'. If this is so, society needs to imagine, and then construct, a society that is rich in all the things that really matter to human flourishing, better diets, better patterns of human movement, etc, but which also consume less of the planet's precious resources. Glasgow, too, needs to be part of a global framework convention on climate change negotiated globally for the end of $2015 .^{88}$ How could Glasgow follow the Royal Society's 'contract and converge' policy proposal, suggested by a committee chaired by a Nobel Laureate, in which the rich should consume less while supporting the 'have-nots' to consume more, and then all manage the transition to sustainability more equitably? ${ }^{89}$ This 'less but better' aspiration is politically delicate even if it is evidence-based.

\section{Foster popular creativity and hope}

Innovation, particularly in technology and energy use, has been one of the means for improving human existence, including its patterns of health, a role hotly debated within public health. While Nobel laureate Robert Fogel saw it as a specific 'techno-economic' driver, Thomas McKeown argued public health gain stemmed from a more general wealth generation. ${ }^{90,91}$ If the transition to a more sustainable future is to be navigated culturally, economically and in other ways, an imaginative map to alternative futures becomes 
essential. Global corporations already seek this to minimise risk but futures thinking is less evident in public health, more wedded to implicitly backwards-looking evidence-based interventions. In cities, however, the fostering of creativity may emerge as the key component for sustainable communities. ${ }^{92}$ Instead of seeing 'health' as limited to public (consumption) goods, the promotion of fun, adventure and art becomes seen as part of the essentials of life and wellbeing. Arguably such creativity has the power to dislodge unhealthy habits - which some see as culturally ingrained in Glasgow - and to provide a new healthy culture of self-affirmation and conviviality. Hope is often the ingredient in shortest supply in deprived communities, but it might be that hope, born of creative responses to current dilemmas, is precisely what is now needed. The argument presented here is that transformational change is to be expected; to that extent it is with Fukuyama's broad thesis, ${ }^{14}$ but as other analysts have argued, the evidence of a clash of financial models and eco-systems services suggests that cities like Glasgow will need to turn even more to the creativity and innovation of their citizens to chart a more healthy sustainable future. ${ }^{93,94}$

Change will occur and opportunities thrown up by change should be seized. In fact this point is hardly new in Glasgow. The crofters who were 'cleared' from the highlands to the shanty towns of Glasgow in the 1830s were also the people who crafted the beautiful city on the Clyde that stands today. The formation of Glasgow, as many cities, exemplifies not just work and energy but the active pursuit of improved conditions for all. This requires a mix of the best traditions of public health. The refocusing of public health envisaged by ecological public health could help foster a similarly radical transformation, not this time for Empire perhaps, but for a more sustainable, equitable and healthy Empire of Health.

\section{Conclusion}

Glasgow provides a mixed picture of health advance. Compared to other former industrial cities in decline, it performs poorly. Many efforts have been made to address this status, with mixed results. Nevertheless, the city has a record of public health advance and of traditions some of which should be defended while others be viewed critically or even abandoned. Following ecological public health thinking, the paper has considered whether it is to time to grasp a particular policy 'nettle', the assumption that any and every form of economic growth will generate health. A particular theme has been presented: that when Glasgow was successful about health in the past, this reflected its creativity. This may be a policy ingredient which could be central to its economic, environmental and social regeneration today. Ecological public health thinking could be helpful here, too, as it places particular emphasis on the interplay of ecosystems health and human health. How to help a city live within its environmental means will need the unleashing of a 'new wave' of public health creativity and cultural change. New goals to shift old habits must infuse a fresh economic vision for the city, a task which faces many cities of the future as well as longestablished ones. 


\section{References}

1. Rayner G, Lang T. Ecological Public Health: Leaders, Movements and Ideas to Shift the Boundaries Between the Normal and the Desirable. In: Butler C, Dixon J, Capon AG, editors. Healthy People, Places and Planet: Reflections based on Tony McMichael's four decades of contribution to epidemiological understanding. Canberra: ANU Press; 2015. 2. $\quad$ Lang T, Rayner G. Ecological Public Health: the 21st century big idea? British Medical Journal. 2012; 345.

3. Office for National Statistics. Life Expectancy at Birth and at Age 65 by Local Areas in the United Kingdom, 2006-08 to 2010-12. London: Office for National Statistics2014 April 162014.

4. Hanlon P, Walsh D, Whyte B. Let Glasgow Flourish, a comprehensive report on health and its determinants in Glasgow and West Central Scotland. Glasgow: Glasgow Centre for Population Health2006.

5. Shaw M, Davey Smith G, Thomas B, Dorling D. The Grim Reaper's Road Map: An Atlas of Mortality in Britain. Bristol: Policy Press; 2008.

6. Walsh D, Taulbut M, Hanlon P. The Aftershock of Deindustrialisation. Trends in mortality in Scotland and other parts of post-industrial Europe. Glasgow: Glasgow Centre for Population Health \& NHS Glasgow2008.

7. Walsh D, Taulbut M, Hanlon P. The aftershock of deindustrialization - trends in mortality in Scotland and other parts of pos-industrial Europe. European Journal of Public Health. 2010; 20:58-64.

8. Walsh D, Bendel N, Jones R, Hanlon P. It's not "just deprivation": why do equally deprived UK cities experience different health outcomes? Public Health 2010; 124:487 - 95.

9. Gray L, Merlo J, Mindell J, Hallqvist J, Tafforeau J, O'Reilly D, et al. International differences in self-reported health measures in 33 major metropolitan areas in Europe. European Journal of Public Health. 2012; 22:40-7.

10. Perry R. Facts and Observations on the Sanitary State of Glasgow, Shewing the Connections Existing Between Poverty, Disease, and Crime. Glasgow: Gartnaval Press1844.

11. Wohl AS. Endangered Lives: Public Health in Victorian Britain. London: Dent; 1983.

12. Hamlin C. Public Health and Social Justice in the Age of Chadwick: Britain, 18001854. Cambridge: Cambridge University Press; 1998.

13. Hardy A. Health and Medicine in Britain since 1860. London: Palgrave; 2000.

14. Fukuyam F. The Great Disruption: Human Nature and the Reconstitution of Social Order. New York: Free Press; 1999.

15. Hanlon P, Carlisle S, Hannah M, Reilly D, Lyon A. Making the case for a 'fifth wave' in Public Health. Public Health. 2011:; 125:30 - 6.

16. Fraser WH. Second City of The Empire: 1830s to 1914 Glasgow: The Glasgow Story: http://www.theglasgowstory.com/story/?id=TGSD02014.

17. McKeown T, Record RG. Reasons for the decline of mortality in England and Wales during the nineteenth century. Population Studies. 1962; 16:94-122.

18. McKeown T, Brown RG. Medical evidence related to English population changes in the eighteenth century. Population Studies. 1955; 9:119-41.

19. Marr JS, Malloy CD. A Brief History and Inventory of Immunizations. Journal of Public Health Management and Practice. 1996; 2:82-6.

20. Craig C. The Tears that Made the Clyde: Well-Being in Glasgow. Glasgow: Argyll Publishing,; 2010. 
21. Crawford F, Beck S, Hanlon P. Will Glasgow Flourish? Regeneration and Health in Glasgow: Learning from the past, analyzing the present, and planning for the future.

Glasgow: Glasgow Centre for Population Health2007.

22. Gibb A. Glasgow: The Making of a City. London: Routledge; 1983.

23. Beveridge SW. Social insurance and allied services, Cmd 6404. London: HMSO1942.

24. Webster C. The National Health Service A Political History. Oxford: Oxford University Press; 1998.

25. Hennessy P. Never again : Britain 1945-51. London: Jonathan Cape; 1992.

26. Grieve R. Inquiry into Housing in Glasgow. Glasgow: Glasgow District Council1986.

27. Donnison D. Conclusions. In: Donnison D, Middleton A, editors. Regenerating the Inner City: Glasgow's Experience. London: Routledge \& Kegan Paul; 1987. p. 272-91.

28. Forwell G. Glasgow's health: old problems, new opportunities. Glasgow: Health Information Unit1993.

29. WHO. The Ottawa Charter for Health Promotion. First International Conference on Health Promotion, Ottawa, 21 November 1986. Geneva: World Health Organisation1986.

30. Ashton J, editor. Healthy Cities. Milton Keynes: Open University Press; 1992.

31. De Leeuw E. Global and local (glocal) health: the WHO healthy cities programme. Global Change and Human Health. 2001; 2:34-45.

32. Green G, Acres J, Price C, Tsouros A. City health development planning. Health Promotion International. 2009; 24:i72-i80.

33. Hancock T. "It's the environment, stupid! Declining ecosystem health is THE threat to health in the 21st century (Commentary). Health Promotion International. 2011; 26:168 72.

34. Hancock T. The Ottawa Charter at 25. Canadian Journal of Public Health. 2011; 102:404-6.

35. World Health Organisation. Countrywide integrated noncommunicable diseases intervention (CINDI) Programme. Copenhagen: WHO Regional Office for Europe1995.

36. Rollnick S. Health Behaviour Change: A Guide for Practitioners. Edinburgh: Churchill Livingstone; 1999.

37. Beck SA, Hanlon PW, Tannahill CE, Crawford FA, Ogilvie RM, Kearns AJ. How will area regeneration impact on health? Learning from the GoWell Study. Public Health. 2010; $124: 125-30$

38. Glasgow City Council. Glasgow City Plan 2:

https://www.glasgow.gov.uk/index.aspx?articleid=2910 Glasgow: Glasgow City Council2009.

39. Scottish Government. Literature Review: Policies Adopted to Support a Healthy Retail Sector and Retail Led Regeneration and the Impact of Retail on the Regeneration of Town Centres and Local High Streets. Edinburgh: Scottish Government2009 january 2009. 40. Jackson T. Prosperity without Growth: Economics for a Finite Planet. London: Earthscan; 2009.

41. Morton T. The Ecological Thought. Cambridge MA: Harvard University Press; 2012.

42. Rayner G, Lang T. Ecological Public Health: reshaping the conditions for good health. Abingdon: Routledge / Earthscan; 2012.

43. Catton WR. Overshoot: the ecological basis of revolutionary change. Chicago: University of Illinois Press; 1982.

44. Rydin Y, Bleahu A, Davies M, Davila JD, Friel S, De Grandis G, et al. Shaping cities for health: complexity and the planning of urban environments in the 21st century. Lancet. 2012; 379:2079-108.

45. Brown LR. Plan B 3.0: Mobilizing to Save Civilization. New York: W.W. Norton \& Company; 2008. 
46. Hanlon P, Carlisle S. Do we face a third revolution in human history? If so, how will public health respond? . Journal of Public Health. 2008; 30:355 - 61.

47. Polanyi K. The Great Transformation. Boston: Beacon Press; 1957.

48. Habitat U. Global Report on Human Settlements 2011 - Cities and Climate Change. New York2011.

49. UN Habitat. Habitat lll: https://www.habitat3.org/ Nairobi: United Nations Habitat Settlements Programme2015.

50. UN Habitat. State of the World's Cities 2010/2011 - Cities for All: Bridging the Urban Divide. London: Earthscan; 2010.

51. Park RE, Burgess EW. The City. Chicago: University of Chicago Press; 1925.

52. Dabla-Norris E, Kochhar K, Suphaphiphat N, Ricka F, Tsounta E. Causes and Consequences of Income Inequality : A Global Perspective. Washington DC: International Monetary Fund2015 June 152015.

53. Ostry JD, Berg A, Tsangarides CG. Redistribution, Inequality, and Growth.

Washington DC: International Monetary Fund2014 February 272014.

54. Girardet H. Creating sustainable cities. Totnes: Green Books for the Schumacher Society; 1999.

55. UN Habitat. State of the World's Cities 2008/2009 - Harmonious Cities Nairboi: UN Habitat2008.

56. UN Habitat. State of African Cities 2010: Governance, Inequalities and Urban Land Market. Nairobi: UN Habitat; 2010.

57. UN Population Division. World Population Prospects: The 2012 Revision.

Washington DC: United Nations2013.

58. Ellen Macarthur Foundation, McKinsey. Towards the Circular Economy. Cowes, Isle of Wight: Ellen Macarthur Foundation2013.

59. European Commission. The Circular Economy: Communication "Towards a circular economy: a zero waste programme for Europe". http://ec.europa.eu/environment/circulareconomy/index_en.htm Brussels: European Commission2014 July 2, 2014.

60. Glover G, Rayner G, Rayner J. The Metabolic Landscape: Perception, Practice and the Energy Transition,. London: Black Dog Publishing; 2014.

61. International Energy Agency. Key World Energy Statistics 2014. Paris: International Energy Agency2014.

62. Hanlon P, McCartney G. Peak Oil: Will it be public health's greatest challenge?

Public Health. 2008; 122:647 - 52.

63. International Energy Agency. Oil Market Report, December 2014.

https://www.iea.org/oilmarketreport/omrpublic/. Paris: International Energy Agency2014.

64. Dickie M. Scotland should be shielded from low oil price, says Salmond. Financial

Times. 2015 April 13 2015;Sect. http://www.ft.com/cms/s/0/279094ba-e208-11e4-9995-

00144feab7de.html?siteedition=uk\#axzz3fgY03Ixn.

65. McKeown T. Medicine in Modern Society. London: Allen \& Unwin; 1965.

66. Foodworks Enquiry. From Food Deserts to Food Security; An alternative vision.

Glasgow: The Poverty Alliance1997.

67. Dobbs R, Smit S, Remes J, Manyika J, Roxburgh C, Restrepo A. Urban world:

Mapping the economic power of cities: McKinsey Global Institute; 2011.

68. Brown EH. The web of debt: the shocking truth about our monetary system and how we can break free. Louisiana: Third Millennium Press; 2007.

69. Randers J. 2052: A report to the Club of Rome commemorating the 40th anniversary of The Limits to Growth. White River Junction VT: Chelsea Green Publishing; 2012.

70. Dobbs R, Lund S, Jonathan Woetzel J, Mutafchieva M. Debt and (not much)

deleveraging. New York: McKinsey Global Institute2015 February. 
71. Stiglitz JE. The Ethical Economist. Foreign Affairs. 2005; 84:128-34.

72. Smith A. The wealth of the nations. Harmondsworth: Penguin; 1776/1970.

73. Smith A. The theory of moral sentiments. Harmondsworth: Penguin; 2010[1759].

74. Rockström J, Steffen W, Noone K, Persson Å, Chapin FS, Lambin E, et al. Planetary boundaries:exploring the safe operating space for humanity. Ecology and Society. 2009;

14:32 online http://www.ecologyandsociety.org/vol14/iss2/art32/.

75. International Council of WSF. World Social Forum 2016:

http://www.fsm2016.org/en/. Quebec: World Social Forum2015.

76. Hanlon P. AfterNOW: http://www.afternow.co.uk/. Glasgow: AfterNOW project2013.

77. People's Health Movement. about PHM: http://www.phmovement.org/. Cape Town, Cairo and Delhi: People's Health Movement2015.

78. Ruppert E, Harvey P, Lury C, Mackenzie A, McNally R, Baker SA, et al. Socialising Big Data: From concept to practice. Manchester: CRESC, The University of Manchester and the Open University2015. Report No.: Working Paper No. 138.

79. WWF, Global Footprint Network, Institute of Zoology, Water Footprint Network. Living Planet Report 2014: Species and spaces, people and places. Gland: WWF International2014.

80. Haines A, McMichael AJ, Epstein PR. Environment and health: 2. Global climate change and health. CMAJ. 2000; 163:729-34.

81. McMichael AJ, Haines A. Global climate change: the potential effects on health. BMJ. 1997; 315:805-9.

82. Watts N, Adger WN, Agnolucci P, Blackstock J, Byass P, Cai W, et al. Health and climate change: policy responses to protect public health. The Lancet. 2015.

83. Honigsbaum M. Anthony Costello: making climate change part of global health. The Lancet. 373:1669.

84. Foresight. Tackling Obesities: Future Choices. London: Government Office of Science2007 October.

85. International Futures Forum. http://www.internationalfuturesforum.com/what-we-do. Aberdour (Fife)2014.

86. Young E, Young A. The New Road. Argyll: Argyll Press,; 2012.

87. Kasser T. The high price of materialism2002.

88. UNFCCC. UN Framework Convention on Climate Change (COP21). Paris. 30

November - 11 December 2015. http://unfccc.int/secretariat/contact/items/2782.php. Bonn

(Germany): United Nations Framework Convention on Climate Change2015.

89. Royal Society. People and the Planet. London: Royal Society 2012.

90. Fogel RW. Technophysio evolution and the measurement of economic growth.

Journal of Evolutionary Economics. 2004; 14:217-21.

91. Fogel RW. The Escape from Hunger and Premature Death, 1700-2100: Europe, America and the Third World. Cambridge: Cambridge University Press; 2004.

92. Eckersley R. Well \& Good: how we feel and why it matters. Melbourne, Australia: Text Publishing; 2004.

93. Donovan P, Hudson J. Red to Green: How the Financial Credit Crunch Could Bankrupt the Environment. London: Earthscan; 2011.

94. Porritt J. The World We Made. London: Phaidon; 2013. 